\title{
A Case of Primary Extracranial Meningioma in the Maxillary Sinus
}

\author{
Sang Hoo Park ${ }^{1}$, Woo Yong Bae ${ }^{1}$ D, Sangjun Kim¹, and Min Gyoung Pak ${ }^{2}$ \\ Departments of ${ }^{1}$ Otorhinolaryngology-Head and Neck Surgery and ${ }^{2}$ Pathology, College of Medicine, Dong-A University, Busan, Korea
}

\section{상악동에 발생한 일차성 두개 외 수막종 1예}

박상후 ${ }^{1} \cdot$ 배우용 ${ }^{1} \cdot$ 김상준 $^{1} \cdot$ 박민경 $^{2}$

동아대학교 의과대학 ${ }^{1}$ 이비인후-두경부외과학교실, ${ }^{2}$ 병리학교실

\author{
Received November 13, 2020 \\ Revised February 23, 2021 \\ Accepted February 25, 2021 \\ Address for correspondence \\ Woo Yong Bae, MD, PhD \\ Department of Otorhinolaryngology- \\ Head and Neck Surgery, \\ College of Medicine, \\ Dong-A University, \\ 26 Daesingongwon-ro, Seo-gu, \\ Busan 49201, Korea \\ Tel $+82-51-240-5428$ \\ Fax +82-51-253-0712 \\ E-mail doncamel@dau.ac.kr
}

Meningioma is one of the most common tumors of the central nervous system. However, primary extra cranial meningioma is rare as it consists $1 \%-2 \%$ of meningioma. It is very rare in paranasal sinus and accounts for about $0.1 \%$ of the paranasal sinus tumor. The treatment of choice is complete surgical excision of the tumor. Herein, with a review of the literature, we report a rare case of primary extra cranial meningioma in a 38 -year-old male.

Korean J Otorhinolaryngol-Head Neck Surg 2022;65(1):45-9

Keywords Endoscopic sinus surgery; Maxillary sinus; Meningioma.

\section{서 론}

수막종은 중추신경계에서 기원하는 종양 중 가장 흔한 종 양으로 두개 내 종양의 $15 \%-20 \%$ 를 차지하고, 두개 내에서 의 연간 발생률은 100000 명당 약 6 명으로 알려져 있다. ${ }^{1)}$ 하지 만 두개 외 영역에서는 잘 발생하지 않는 것으로 알려져 있고, 두개 외 영역에서 원발하는 경우는 전체 수막종의 약 $1 \%-$ $2 \%$ 정도를 차지한다. 두개 외 수막종은 안와에 가장 많이 발 생하는 것으로 보고되고 있고, 그 이외에 귀, 코, 부비동, 이 하선, 목, 인두 등에도 발생할 수 있다. ${ }^{2)}$ 부비동에 발생하는 두개 외 수막종은 매우 드문 질환으로, 부비동에 발생하는 종양의 약 $0.1 \%$ 정도로 알려져 있다. ${ }^{3)}$ 국내에서는 사골동에 서 원발한 수막종에 대한 증례가 1 회 보고된 바 있지만, 상악

This is an Open Access article distributed under the terms of the Creative Commons Attribution Non-Commercial License (https://creativecommons.org/licenses/by-nc/4.0) which permits unrestricted non-commercial use, distribution, and reproduction in any medium, provided the original work is properly cited.
동에서 원발한 수막종에 대한 증례는 보고된 바 없기에, 본 저자들은 상악동에 발생한 수막종 1 예를 문헌 고찰과 함께 보고하는 바이다.

\section{증 레}

38 세 남자 환자가 약 2 개월 전부터 간헐적으로 발생하는 코막힘을 주소로, 타병원에서 촬영한 부비동 전산화 단층촬 영 $(\mathrm{CT})$ 과 조직검사에서 신경 섬유종이 의심되어 추가 검사 및 수술을 위해 본원으로 내원하였다. 내원 당시 코막힘 이외 콧물, 기침, 코피 등의 다른 증상은 호소하지 않았고 특이한 과거 병력 및 수술 병력도 없었다. 외래에서 시행한 내시경 검 사에서 조직검사 후 발생한 것으로 의심되는 유착 소견 외 다 른 소견은 관찰되지 않았다(Fig. 1). 본원에서 촬영한 CT 소 견에서 우측 상악동에 다수의 작은 석회화가 동반되는 종양 이 확인되었으며, 영상의학과에서는 섬유조직이 풍부한 골화 
섬유종 혹은 신경섬유종으로 판독하였다(Fig. $2 \mathrm{~A}$ and $\mathrm{B}$ ). $\mathrm{CT}$ 에서 두개골 윤곽이 종양의 침범 소견없이 잘 유지되어 있 고, 종양이 두개 내 영역을 침범한 소견은 보이지 않아 두개 외 영역에서 기원한 것으로 생각할 수 있었다(Fig. 2C). 부비 동 자기공명영상(MRI)에서 우측 상악동을 가득 채우는 종 양이 확인되었고, T1, T2 강조영상에서 저강도 신호를 보이며 균일한 조영 증강을 보였다(Fig. 3). 또한 종양에 분포하는 영 양 동맥(nutrient artery)이 있는 것으로 판단되어 혈관조영 술을 시행하였고, 병변으로 침입한 나비입천장동맥(sphenopalatine artery)에서 기원하는 영양 동맥이 발견되어 polyvinyl alcohol을 이용하여 색전술을 시행하였다(Fig. 4). 색전 술 시행 2일 뒤 전신마취하에 내시경하 절제술(endoscopic sinus surgery)과 상악동 근치술(Caldwell-Luc operation)을 시행하여 수술을 진행하였다. 종물은 경계가 명확하였으나 단단하고 크기가 커서 내시경하 절제술만으로는 종물을 완 전히 제거하는 데 한계가 있어 내시경하 절제술 및 상악동 근

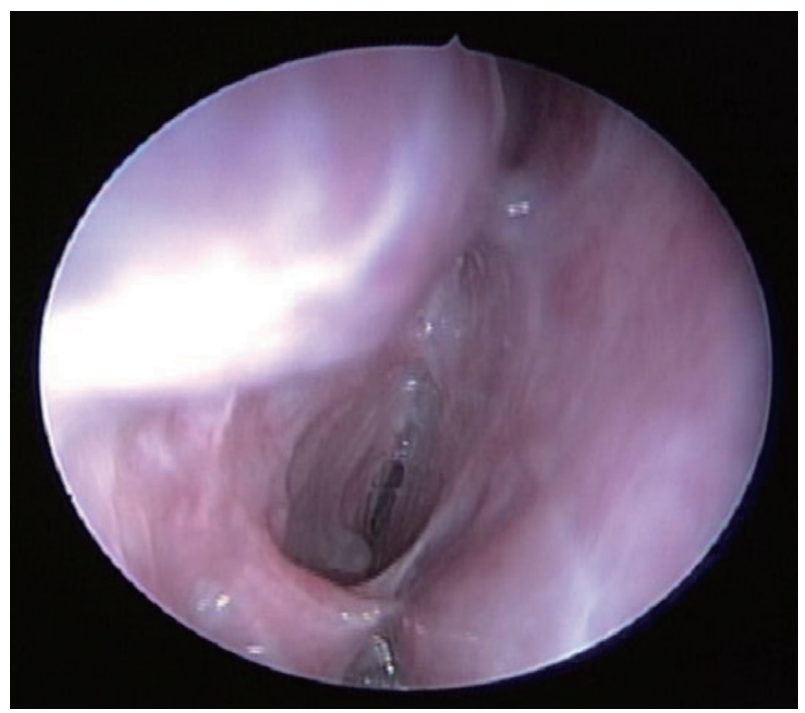

Fig. 1. Pre-operation endoscopic imaging of right nasal cavity.
치술을 함께 시행하여 부분적으로 종물을 제거하면서 완전 절제를 시행하였다(Fig. 5). 병리조직학적 소견상 종양은 방 추형의 세포(spindle cell)로 구성되어 있고 석회화를 동반하 고 있었다. 종양 세포 핵의 비정형 소견(atypism)이나 유사분 열(mitotic figure), 국소 괴사 소견은 관찰되지 않았다(Fig. 6A and B). 면역조직화학염색에서 pan-Cytokeratin 항체에 대해 음성을 보여 전이성 종양을 배제할 수 있었고, $\mathrm{MIB}-1$ labelling index (LI)는 전체 종양 세포의 $1 \%$ 미만에서 양성 을 보여 1 등급 수막종에 해당하는 섬유성 수막종으로 최종 진단되었다(Fig. 6C). 환자는 술후 7일째 퇴원하였으며 합병 증 및 병변의 재발 소견없이 3 개월간 외래 추적 관찰 중이다.

\section{고 찰}

수막종은 대부분 두개 내 영역에서 발생하는 양성의 천천 히 자라는 종양으로 알려져 있다. 두개 외 영역에서 원발하는 경우는 전체 수막종의 약 1\%-2\% 정도를 차지한다고 알려져 있으며 발생이 드물다. 비강에서는 주로 코, 상악동, 전두동 에서 발생하며, 사골동에서도 발생할 수 있으나 접형동에서의 발생은 드물다. 두개 외 영역과 두개 내 영역의 해부학적 관 계에 따라서 두개 외 수막종은 원발성, 이차성 종양으로 분류 할 수 있다. 이차성 종양은 두개 내 영역으로부터 종양이 연결 되어 있으며 대부분의 두개 외 수막종은 이차성 종양이다.) Daneshi 등ㄱ은 원발성 종양을 전이성 종양 혹은 이차성 종 양과 정확하게 감별할 수 있도록 3 가지 기준을 제시하였다 (Table 1). 본 증례에서는 전산화단층촬영, 자기공명영상, 혈 관조영술 등의 영상 검사뿐만 아니라, 수술을 통해서도 환자 의 병변이 두개 내 연결이 없는 원발성 두개 외 수막종임을 확인할 수 있었다. 원발성 두개 외 수막종의 기원은 아직 정 확히 밝혀지지 않았지만, 뇌신경의 말이집(myelin sheath)에 존재하는 지주막세포로부터 원발성 두개 외 수막종이 기원
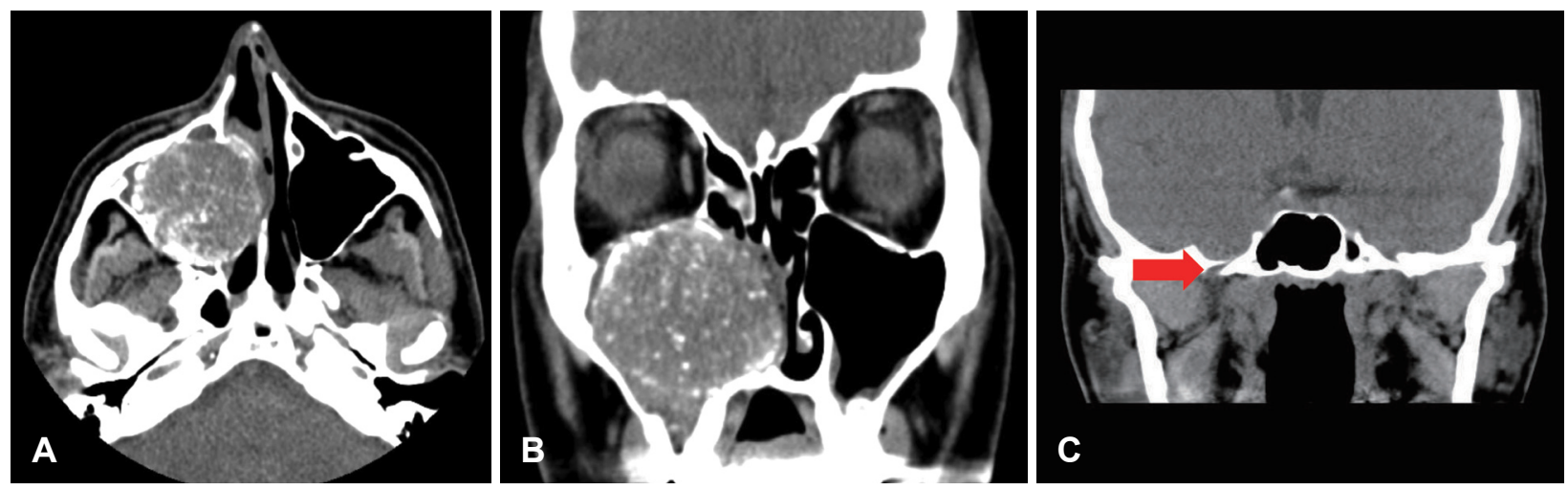

Fig. 2. Preoperative CT scan. Paranasal sinus CT shows an expansile mass with multiple calcification in the right maxillary sinus on axial (A) and coronal view (B). C: Paranasal sinus CT shows well maintained bony contour of temporal bone skull base with foramen ovalis (arrow) on coronal view. 

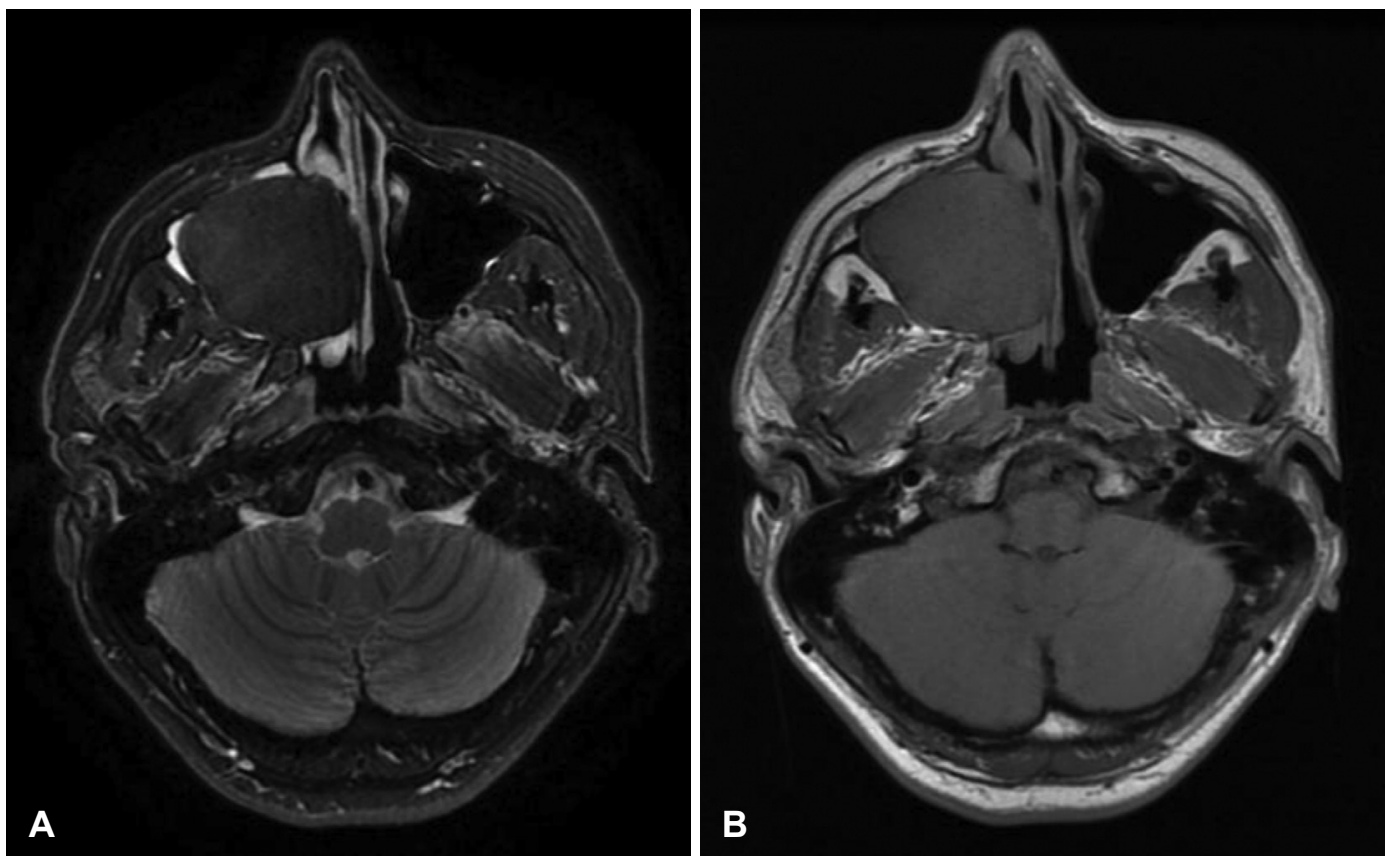

Fig. 3. Magnetic resonance image of paranasal sinus shows expansile mass with low signal in T2 weighted image (A) T1 weighted image (B).
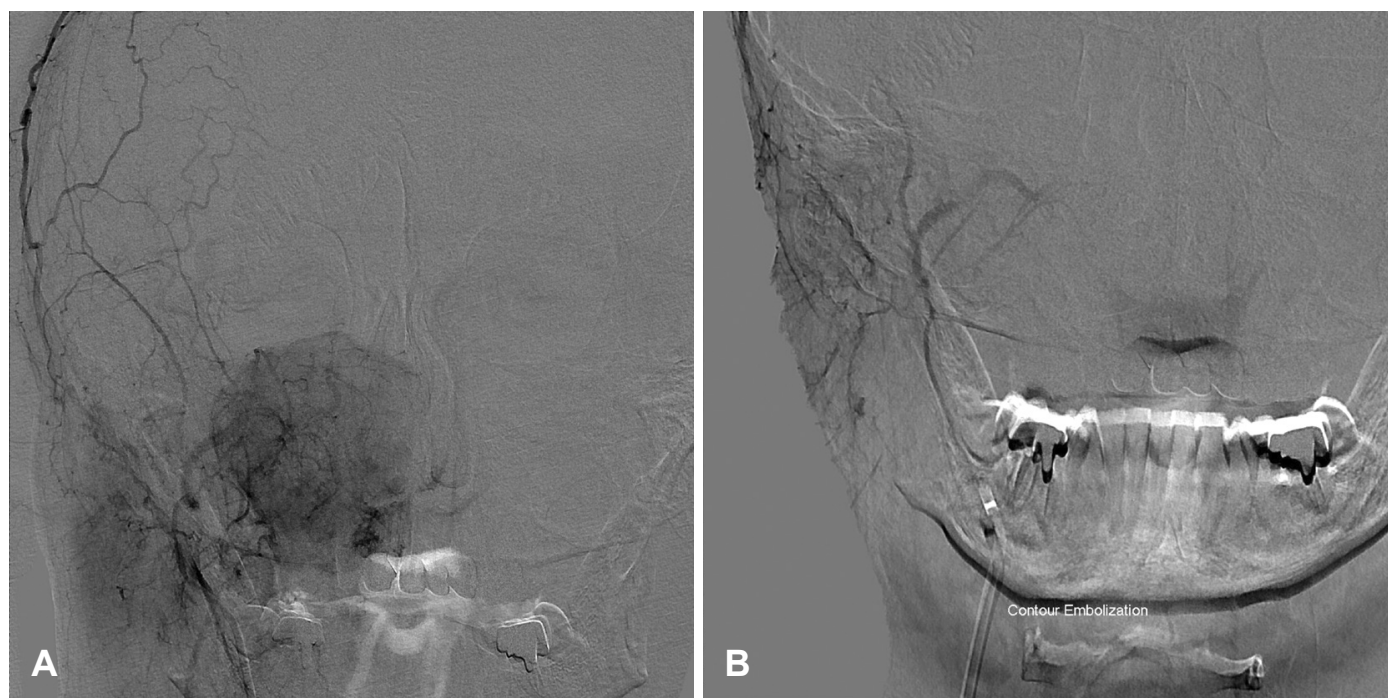

Fig. 4. Right common carotid artery angiography, axial view. A: It shows tumor blush at the right maxillary sinus. Nutrient arterial supply is originated from the right sphenopalatine artery. B: The tumor disappeared after polyvinyl alcohol embolization through the sphenopalatine artery.

한다는 가설이 받아들여지고 있다. ${ }^{6)}$ 증상은 관련된 부비동 에 따라 다양하게 나타날 수 있다. 전두동을 침범한 경우 안 구돌출, 시력저하, 두통 등이 발생할 수 있고 상악동을 침범 한 경우 뺨이 부을 수도 있다. ${ }^{7}$ 영상학적으로 전산화단층촬 영과 자기공명영상촬영이 수막종의 진단에 유용하다고 알려 져 있다. T1 강조영상에서는 등강도 또는 약간의 저강도를 보 일 수 있으며, T2 강조영상에서는 종양의 혈관분포상태나 석 회화 정도에 따라 다양한 신호강도를 보일 수 있다. 수막종은 조직학적으로 수막세포형(meningotheliomatous), 섬유모세 포형(fibroblastic), 이행형(transitional), 혈관종성(angiomatous), 미세낭형(microcystic) 등으로 분류할 수 있다. 최근에 는 자기공명영상의 신호강도와 종양의 조직병리학적 아형의 연관성에 관한 연구 결과가 보고되고 있다. T1 강조영상은 수 막종의 아형과 상관없이 비슷한 양상을 보이지만 섬유모세 포성 수막종으로 확진된 경우 $\mathrm{T} 2$ 강조영상에서 비교적 저강 도 신호를 보인다고 알려져 있다. ${ }^{8)}$ 본 증례의 경우도 조직검사 후 다시 MRI 결과를 확인한 결과 섬유모세포성 수막종에 해 당되는 소견을 확인할 수 있었다. 

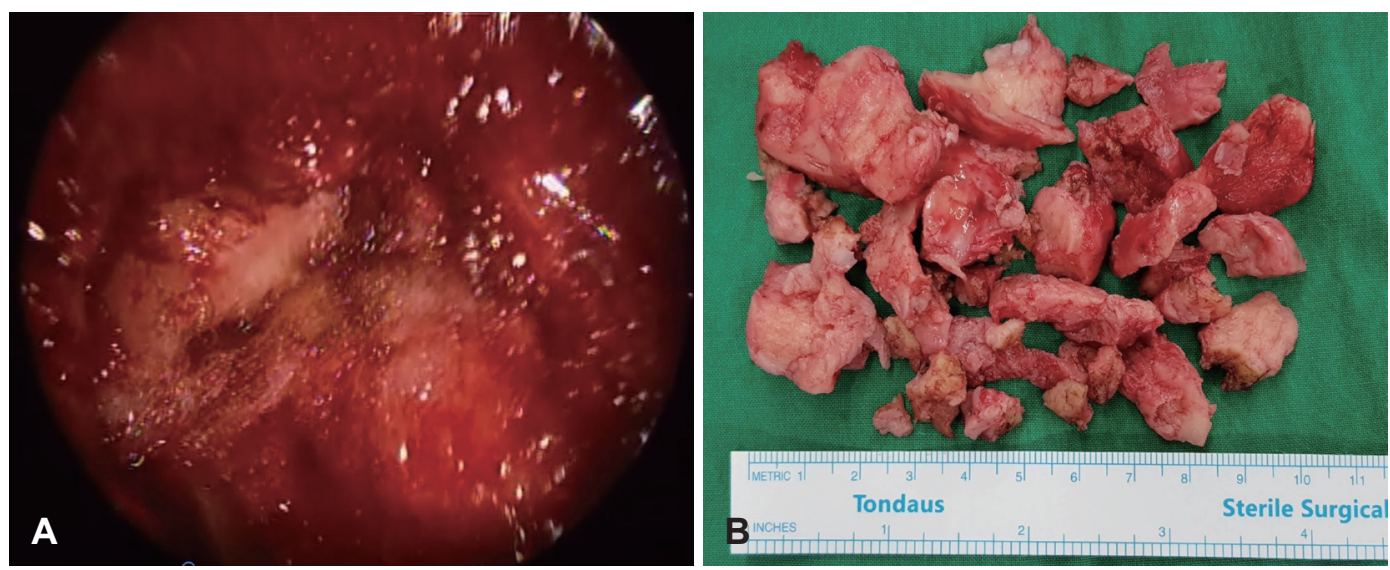

Fig. 5. Gross image of meningioma. A: Intra-operative image of meningioma. B: Gross photo of meningioma after operation.
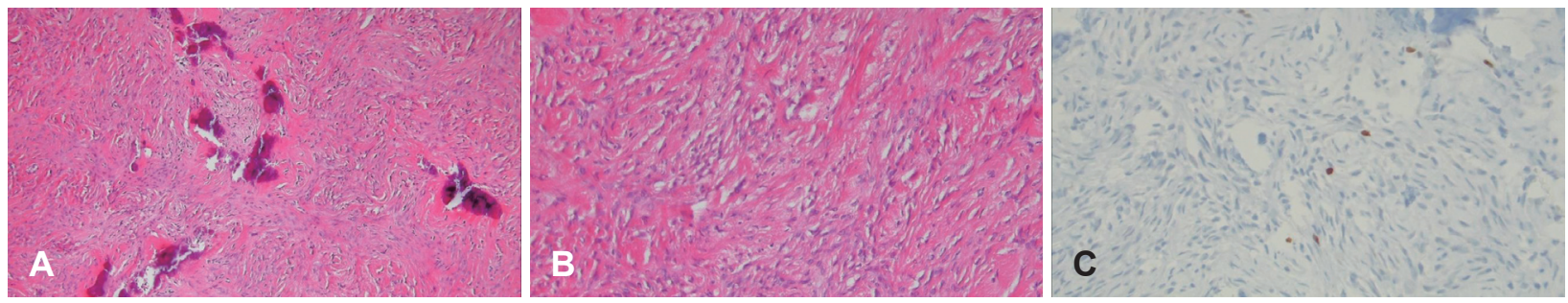

Fig. 6. Pathological findings. A: The tumor cells admixed with dystrophic calcification form fascicles parallel or storiform pattern (H\&E, $\times 100)$. B: The tumor consists of spindle cells without obvious mitotic figures or atypism (H\&E, $\times 200)$. C: The MIB-1 (Ki-67) labelling index is less than $1 \%$ (MIB-1, $\times 400)$. H\&E, hematoxylin and eosin.

Table 1. Three criteria to differentiate paranasal sinus meningiomas from metastatic meningioma or those extending from intracranial tumors

\begin{tabular}{l} 
Criteria \\
\hline 1. The bony wall of the sinus is intact on radiological imaging \\
or on inspection during surgery \\
2. The absence of a simultaneous intracranial meningioma on \\
imaging or at surgery \\
3. Expansion of the sinus wall towards the cranium rather than \\
to the opposite direction
\end{tabular}

술전 정확한 수술 계획을 위해 전산화단층촬영, 자기공명 영상 촬영 등이 필요하며, 영상에서 종양으로의 혈관 침범이 의심되면 혈관조영술 및 색전술을 시행하여 수술 중 발생할 수 있는 출혈의 위험성을 줄일 수 있다. ${ }^{9}$ 본 증례의 경우에도 자기공명영상촬영 판독 중 영양 동맥이 확인되어 색전술을 시행한 후 수술을 진행하였다.

원발성 두개 외 수막종의 치료는 수술적 완전절제이다. 수 막종은 방사선 저항성을 가지고 있는 종양이기 때문에 수술 이 불가능하여 완화 치료를 고려하는 경우에서만 방사선 치 료를 시행한다. ${ }^{10)}$ 병변이 충분히 제거된 경우 재발은 거의 없 는 것으로 보고된다.

상악동에서 기원하고 국한된 원발성 두개 외 수막종은 국 외에서 총 5예 보고되었고 국내에서는 보고된 바가 없었다.
Table 2. Summary of the characteristics of primary extra cranial meningioma from the maxillary sinus

\begin{tabular}{|c|c|c|c|}
\hline Case & Author & Sex/age & Surgical approach \\
\hline 1 & Aiyer, et al. ${ }^{3)}$ & $F / 23$ & Lateral rhinotomy \\
\hline 2 & Nozaki, et al. ${ }^{8)}$ & $M / 14$ & Intraoral approach \\
\hline 3 & Lingen, et al. ${ }^{11)}$ & $M / 50$ & Total maxillectomy \\
\hline 4 & Manni ${ }^{12)}$ & $M / 23$ & Lateral rhinotomy \\
\hline 5 & Kohsyuu and Kikuchi ${ }^{13)}$ & $M / 19$ & Not described \\
\hline
\end{tabular}

국외에서 보고된 총 5 예를 분석하였다(Table 2). 평균 연령은 26세였으며 남성이 4명(80\%)으로 더 높은 비율을 차지하였 다. Case 1, 4는 측비절개술로 수술을 시행하였으며, ${ }^{3,12}$ case 2는 구강 내 접근을 통해 첫 번째 어금니 및 송곳니와 함께 종괴를 절제하였다.8) Case 3은 상악골전절체술로 종양을 전 체 절제하였으며, ${ }^{11)}$ case 5 는 수술 방식이 묘사되어 있지 않 았다. ${ }^{13}$

대부분의 수막종은 원격 전이를 일으키지 않고 악성으로의 전환도 매우 드물기 때문에 정기적으로 추적 관찰하면 환자 의 예후는 좋은 것으로 알려져 있다. ${ }^{3)} \mathrm{Ho}$ 등 $^{14}$ 은 MIB-1 LI 가 $10 \%$ 미만인 수막종은 10년 이내 재발하지 않는다고 보고 하였고, 병변의 충분한 절제와 낮은 MIB-1 LI가 수막종 경 과의 좋은 예후 인자로 알려져 있다. ${ }^{15)}$ 본 증례에서는 MIB-1 $\mathrm{LI}$ 가 전체 종양세포의 $1 \%$ 미만으로 확인되었고 병변의 충분 한 수술적 절제가 이루어져 예후는 좋을 것으로 예상된다. 


\section{Acknowledgments}

None.

\section{Author Contribution}

Conceptualization: Woo Yong Bae. Data curation: Min Gyoung Pak. Formal analysis: Sangjun Kim. Investigation: Sang Hoo Park. Project administration: Woo Yong Bae. Supervision: Sangjun Kim. Writing — original draft: Sang Hoo Park. Writing — review \& editing: Woo Yong Bae.

\section{ORCIDs}

Woo Yong Bae https://orcid.org/0000-0001-5578-0225

Sang Hoo Park

\section{REFERENCES}

1) Longstreth WT Jr, Dennis LK, McGuire VM, Drangsholt MT, Koepsell TD. Epidemiology of intracranial meningioma. Cancer 1993;72(3):639-48.

2) Landini G, Kitano M. Meningioma of the mandible. Cancer 1992; 69(12):2917-20.

3) Aiyer RG, Prashanth V, Ambani K, Bhat VS, Soni GB. Primary extracranial meningioma of paranasal sinuses. Indian J Otolaryngol Head Neck Surg 2013;65(Suppl 2):384-7.

4) Ho KL. Primary meningioma of the nasal cavity and paranasal sinuses. Cancer 1980;46(6):1442-7.

5) Daneshi A, Asghari A, Bahramy E. Primary meningioma of the ethmoid sinus: A case report. Ear Nose Throat J 2003;82(4):310-1.

6) Wolff M, Rankow RM. Meningioma of the parotid gland: An insight into the pathogenesis of extracranial meningiomas. Hum

Pathol 1971;2(3):453-9.

7) Gökduman CA, Iplikcioglu AC, Kuzdere M, Bek S, Cosar M. Primary meningioma of the paranasal sinus. J Clin Neurosci 2005; 12(7):832-4.

8) Nozaki S, Yamazaki M, Koyama T, Kubota Y, Kitahara H, Yoshizawa K, et al. Primary extracranial meningioma of the maxillary sinus presenting as buccal swelling. J Oral Maxill Surg 2011;23(3):134-7.

9) Friedman CD, Costantino PD, Teitelbaum B, Berktold RE, Sisson GA Sr. Primary extracranial meningiomas of the head and neck. Laryngoscope 1990;100(1):41-8.

10) Swain RE Jr, Kingdom TT, DelGaudio JM, Muller S, Grist WJ. Meningiomas of the paranasal sinuses. Am J Rhinol 2001;15(1):2730.

11) Lingen MW, Rao SM, Hutten MC, Pelzer HJ. Primary ectopic meningioma of the maxillary sinus: Case report and review of the literature. Head Neck 1995;17(3):258-62.

12) Manni JJ. Ectopic meningioma of the maxillary sinus. J Laryngol Otol 1983;97(7):657-60.

13) Kohsyuu H, Kikuchi A. A case of primary extracranial meningioma in the maxillary sinus. Practica Oto-Rhino-Laryngologica 1991; (51):227-31.

14) Ho DM, Hsu CY, Ting LT, Chiang H. Histopathology and MIB-1 labeling index predicted recurrence of meningiomas: A proposal of diagnostic criteria for patients with atypical meningioma. Cancer 2002;94(5):1538-47.

15) Kim YJ, Ketter R, Henn W, Zang KD, Steudel WI, Feiden W. Histopathologic indicators of recurrence in meningiomas: Correlation with clinical and genetic parameters. Virchows Arch 2006;449(5):529-38. 